\begin{tabular}{|l|l|l||}
\hline \multicolumn{2}{|c|}{ PublisherInfo } \\
\hline \hline PublisherName & $:$ & BioMed Central \\
\hline \hline PublisherLocation & $:$ & London \\
\hline \hline PublisherImprintName & $:$ & BioMed Central \\
\hline \hline
\end{tabular}

\title{
More efficient transposon mutagenesis in Arabidopsis?
}

\begin{tabular}{|l|l|l||}
\hline \multicolumn{2}{|c|}{ ArticleInfo } \\
\hline \hline ArticleID & $:$ & 3562 \\
\hline \hline ArticleDOI & $:$ & $10.1186 /$ gb-2000-1-1-reports028 \\
\hline \hline ArticleCitationID & $:$ & reports028 \\
\hline \hline ArticleSequenceNumber & $:$ & 53 \\
\hline \hline ArticleCategory & $:$ & Paper report \\
\hline ArticleFirstPage & $:$ & 1 \\
\hline \hline ArticleLastPage & $:$ & 4 \\
\hline \hline & & RegistrationDate : 2000-2-1 \\
ArticleHistory & $:$ & Received \\
\hline \hline ArticleCopyright & $:$ & BioMed Central Ltd2000-2-1 \\
\hline \hline ArticleGrants & $:$ & \\
\hline \hline ArticleContext & $:$ & 130591111 \\
\hline \hline
\end{tabular}




\section{Abstract}

A maize transposable element has been used to generate a tool for identifying gene function in Arabidopsis thaliana.

\section{Significance and context}

Mutational analysis is crucial for defining the biological role of a gene. In the case of a gene that has been sequenced, but for which no mutant is known, mutations can be found using 'reverse-genetic' techniques and the phenotype determined. In Arabidopsis thaliana, this mainly involves transformation with the bacterium Agrobacterium tumefaciens, which integrates its transfer DNA (T-DNA) into the plant genome. Individual mutagenized plants can then be screened for the desired mutation by PCR using primers specific for the gene of interest and the inserted DNA. Speulman et al. report a new reverse-genetic resource in the form of transgenic Arabidopsis containing the maize transposable elements Enhancer (En, also called Spm) and Inhibitor (I, also called $d S p m$ ). The autonomous En element encodes a transposase that induces its own transposition and excision as well as that of the nonautonomous $I$ element. Unlike T-DNA insertions, the $E n-I$ system increases in the number of copies of $I$, and therefore the number of insertions, in subsequent generations; thus, fewer plants should need to be produced to obtain mutational saturation of the genome.

\section{Key results}

To assess the frequency and distribution of transpositions, the regions flanking the insertions in 17 lines, which had been outcrossed to segregate away the En element, were cloned, and the sequences compared with known Arabidopsis sequences. Of these sequences, 74\% showed similarity to known sequences and $65 \%$ could be located to a chromosomal region. Insertions were found all over the genome, but about $10 \%$ were positioned near the site of the original insertion in the progenitor plant, suggesting that $I$ transposes to linked sites. The methodology was tested by screening for insertions both in cloned genes with well described mutant phenotypes and in a cloned gene for which no mutant phenotype was known. For example, insertions into the gene FATTY ACID ELONGATION1 (FAE1) were used to show that a phenotype identical to that of the FIDDLEHEAD ( $f d h)$ mutant wasassociated with this gene.Independent experiments have recently confirmed thatthe $f d h$ locus is encoded by the 
FAE1 gene. It is also possible to use these stocks in a 'forward', or traditional, genetic approach by visual inspection for a phenotype of interest.

\section{Methodological innovations}

Arabidopsis plants were transformed with a single construct containing both the En and $I$ elements and a selectable marker.A single line containing two insertions (T-En2 and T-En5), located on chromosomes 1 and 2, respectively, was self-pollinated repeatedly to increase the copy number of the transposable element. The resulting $216 \mathrm{~T}-E n 5$ homozygotes identified were selected as progenitors of 2,592 single-seed descent lines produced by self-pollination. DNAs from the single-seed lineswere arranged in a three-dimensional array to facilitate location of a specific insertion by a coordinate system.

\section{Links}

The Nottingham Arabidopsis stock center (NASC) maintains several collections of T-DNA and transposon insertion lines that are publicly available including subpools of lines described in this paper. The Sequenced insertion sites (SINS) database shows BLAST similarities of the flanking regions of 1,200 Spm insertions, seed from which are also available from NASC. A Ds insertion database is also available. The Wisconsin T-DNA knockout facility will perform a primary screen of their library of TDNA insertions and supply seed for further analysis of positive lines. The Arabidopsis Information Resource (TAIR) contains many tools and resources for Arabidopsis researchers.

\section{Reporter's comments}

The insertional mutagenesis technique described here will be a useful tool for plant researchers who want to attribute function to genes identified by sequence alone. As expected, the number of insertions per plant is higher than that of previously described T-DNA insertion populations. However, it has been shown experimentally that about $50 \%$ of the putative positive insertions are not heritable, effectively reducing the number of insertions that result in an analyzable phenotype. This is most likely to be due to instability of the transposable element. Unstable insertions can, however, be useful for identifying revertants. $I$ appears to insert into regions of the genome rich in A:T basepairs, which may result in a preference for insertions into regulatory regions and introns rather than into exons. Thus, different classes of mutation might be obtained from this resource. Combined with the output of other reversegenetics tools, this provides a valuable resource for plant biologists seeking mutations in particular genes. 


\section{Table of links}

Plant Cell

Nottingham Arabidopsis stock center

Sequenced insertion sites

Ds insertion database

Wisconsin T-DNA knockout facility

The Arabidopsis Information Resource

\section{References}

1. Speulman E, Metz PLJ, Arkel G van, Hekkert B te Lintel, Stiekema WJ, Pereira A: A two component Enhancer-Inhibitor transposon mutagenesis system for functional analysis of the Arabidopsis genome. Plant Cell. 1999, 11: 1853-1866. 1040-4651

This PDF file was created after publication. 